drivers were involved in crashes while smoking. In 1944, smoking was banned on trains and buses in cities. It was also prohibited in many workplaces, public buildings, hospitals, and rest homes. The advertising of smoking products was strictly controlled, and there was discussion on whether people with smoking related illnesses should receive medical care equal to that of patients with illnesses not seen to be self inflicted. Many leading Nazis-such as Robert Ley, leader of the German Labour Front, Hans Reiter, president of the Reich Health Office, and both Gerhard Wagner and Leonardo Conti, the successive Führers of German medicine-attested to the benefits of not smoking. Adolf Hitler was the star performer in antismoking propaganda. As one magazine stated, "Brother national socialist, do you know that your Führer is against smoking and thinks that every German is responsible to the whole people for all his deeds and missions, and does not have the right to damage his body with drugs?"

Smoking was only one of the health related behaviours that received attention in Nazi Germany. The consumption of alcohol was also strongly campaigned against. Fruit and vegetable consumption was encouraged, as was the use of wholemeal bread and the avoidance of fat. ${ }^{1}$ A key figure in Nazi medicine, Erwin Liek, predicted that cancer would come to be seen as a product of diet. ${ }^{2}$ The consumption of whipped cream seems to have been a particular target of disapproval. The official newspaper of the SS, Das Schwarzes Korps, reported on German tourists in Austrian coffee houses and said that anyone would "think Greater Germany was only created so that this raving Philistine rabble can wolf whipped cream." A prominent promilitarist slogan read, "Fighting power or whipped cream?" Considerable interest was shown in the notion that a poor intrauterine environment would have long term deleterious effects on offspring. A 1942 health manual proclaimed "mothers, you must absolutely avoid alcohol and nicotine during pregnancy and when nursing. They hinder, they harm, they disrupt the normal course of pregnancy. Drink fruit juice." A public health

\section{Summary points}

In Nazi Germany considerable research and antismoking health promotion was carried out

The consumption of alcohol was also strongly campaigned against

Promoting these lifestyles fitted in with the racial hygiene movement but also covered up the fact that health in Nazi Germany deteriorated

film exhorted the German people that they "can and must maintain their health through a sensible lifestyle."

Clearly there were considerable links between the promotion of particular lifestyles and the racial hygiene movement. ${ }^{13}$ Tobacco and alcohol were seen as "genetic poisons," leading to degeneration of the German people. Since racial hygiene has been so strongly linked to the horrors of the Nazi regime, particularly the murder campaigns against Jews, homosexuals, travellers, and those deemed to be mentally and physically defective, there was resistance to the authoritarian control of lifestyles. An émigré Jewish physician and campaigner against the Nazi regime, Martin Gumpert, considered the lifestyle campaigns to be a cover up for the fact that health in Nazi Germany deteriorated dramatically. ${ }^{4}$ Gumpert proclaimed that the "abstinent Hitler, who from conviction never takes a drop of alcohol ... now drives the people at whose head he stands into fatal alcoholism."

Contributors: GDS is sole contributor.

Competing interests: None declared.

1 Proctor RN. Racial hygiene. Medicine under the Nazis. Cambridge, MA: Harvard University Press, 1988.

2 Schairer E, Schöniger E. Lungenkreb sund Tabakverbrauch. Z Krebsforsch 1943;54:261-9. (Reprinted in Int J Epidemiol 2001;30:24-7.)

3 Davey Smith G, Ströbele SA, Egger M. Smoking and health promotion in Nazi Germany. J Epidemiol Community Health 1994;48:220-3.

4 Gumpert M. Heil hunger!! health under Hitler. London: Allen and Unwin, 1940.

\title{
Is democracy good for people's health? A South African perspective
}

\author{
Dan J Ncayiyana
}

What is democracy? There are probably as many versions of this elastic concept as there are countries and nations that claim to be its adherents (and there is nary a country that does not)-something that is bound to confound attempts to tackle the question that constitutes the subject of this essay. Both Plato and Aristotle were contemptuous of the idea of democracy meaning direct rule by the populace or "the mob" as in Athens; they favoured instead the idea of "rule by the best"- the aristocracy (aristos is Greek for "best").

The Aristotelian model underpins modern representative governance. The governed are afforded the opportunity periodically to elect "the best," who will rule over them. Once elected, the ruling elite makes decisions about war and peace, the quality of the environment, the allocation of the nation's resources, and other critical matters, all of which have profound implications for the health of the people-decisions that do not always reflect what the people regard as best for their health.

Another semantic ambiguity is the concept of "people's health." The World Health Organization's definition of health as a "state of complete physical, mental and social well-being and not merely the absence of disease or infirmity" casts a very wide net, leaving the

A table showing rates for health indicators over the past decade is on bmi.com 


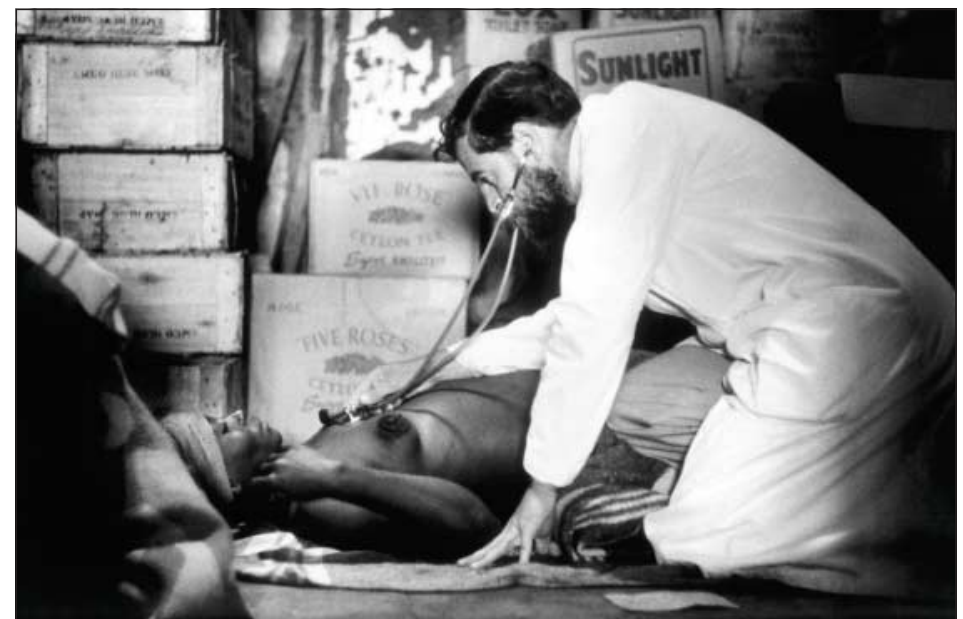

In 1961, missionary doctors were using warehouses for their clinics

epidemiologists scrambling to formulate health indicators to measure the effectiveness of health systems.

South Africa became a representative democracy on 7 April 1994, the historic day when citizens of every colour and persuasion flocked to the polls to elect the first unitary non-racial government, with Nelson Mandela as the first president. Cynics have averred that with the change, an Aristotelian aristocracy characterised by "struggle credentials" now came to replace the white oligarchy, albeit with overwhelming popular support. The new government inherited 14 independent health departments: one for each of the 10 black homelands; one each for the white, brown (mixed descent) and Asian communities; and one for black Africans living and working in so called white South Africa.

Health resources used to be unabashedly skewed in favour of services for the white community. Separation between black and white services was so absolute that an empty ambulance for white South Africans happening upon a serious road crash would blithely drive by if the casualties were black. ${ }^{1}$ Chief among the priorities of the new government was to merge these separate bureaucracies and operational systems to create a single, deracialised national health system, something the rulers were able to achieve with remarkable success.

The South African Bill of Rights, one of the most comprehensive in the world, declares that "everyone has the right to have access to health care services." Accordingly, access and equity constitute the cornerstones of the government's new health policy, with primary care at centre stage. To achieve this goal, funding has been redistributed between and within provinces,

\section{Summary points}

South Africa elected a unitary non-racial government in 1994

One of the priorities was to create a single, deracialised national health system

Primary care is at the centre of the new health policy

Since 1994, though, unemployment and poverty, and HIV/AIDS have increased, and health indicators have worsened and from tertiary to primary care, bringing health care closer, particularly to rural poor South Africans. Ironically, the reallocation has virtually decimated academic hospitals and accelerated the flight of academic staff from the public service. Public sector user fees were abolished, and an essential drugs list was introduced that greatly improved the availability and accessibility of medicines. More district health clinics were established, and more of them were connected to electricity and running water.

Has the health of the people improved in the decade since democracy? Not according to the health indicators, such as maternal, infant, and perinatal mortality; child nutrition; tuberculosis prevalence; and life expectancy (see table on bmj.com). ${ }^{2}$ In certain instances, the reverse is evident. Unemployment and poverty (identified by WHO as the foremost threat to health) have increased despite a relatively robust economy. ${ }^{3}$ And while the proportion of economically successful black South Africans has grown substantially, the gap between the haves and the have-nots has widened. HIV/AIDS has worsened (something for which the government is taking a lot of knocks) and is largely responsible for the regression in health indices such as infant and child mortality, tuberculosis and life expectancy.

Until and unless South Africa is able to deal with the twin evils of poverty and HIV/AIDS, the future of the health of the people will remain bleak, and the newly won democracy will seem like a pyrrhic victory in so far as people's health is concerned.

Baldwin-Ragaven L, de Gruchy J, London L. An ambulance of the wrong colour. Cape Town: UCT Press, 1999.

Ijumba P, Day C, Ntuli A, eds. South African health review 2003/04. Durban: Health Systems Trust, 2004.

Poverty and Inequality in South Africa. Report prepared for the Office of the Executive Deputy President and the Inter-Ministerial Committee for Poverty and Inequality. May 1998 . www polityorg za/html/govdocs reports/poverty.html (accessed 8 Dec 2004).

\section{The Hooper's bed}

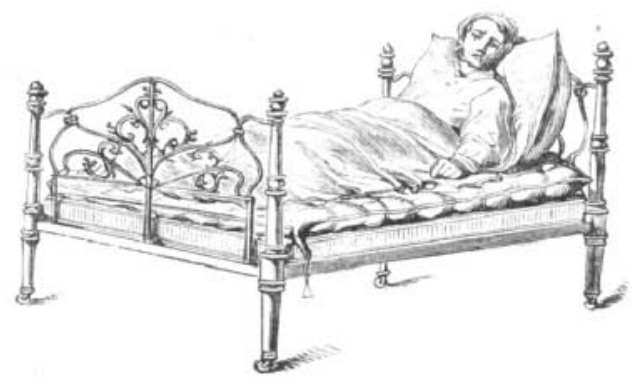

A water flotation mattress was used at the St George Hospital to prevent pressure sores, as described by Professor Ch. Sarazin of the Medical School of Strasbourg in his pamphlet Essai sur les Hopitaux de Londres (Essay on the London Hospitals) published in 1866. Professor Sarazin gives credit for this invention to William Hooper of London, an ingenious artisan who probably made the mattress at the suggestion of Caesar Hawkins of the St George Hospital, who first described the device, remarkably similar to those we still use today, in a letter to the Lancet.

Claudio Crisci chief consultant, “Clinic Center," Private Hospital for Rehabilitation, Naples, Italy (claudio.crisci@cliniccenter.it) 